\title{
ДІАГНОСТИКА УЯВЛЕНЬ ПЕДАГОГІЧНИХ ПРАЦІВНИКІВ ЩОДО ЕФЕКТИВНОСТІ ВЛАСНОЇ НАВЧАЛЬНОЇ ДІЯЛЬНОСТІ
}

Удк: 159.9 .072

\section{Гальцева Тетяна Олексївна}

Кандидат психологічних наук, доцент, доцент ка-
федри соиіально-гуманітарних дисииллін Дніпропе-
тровського державного університету внутрішніх справ, м. Дніпро (Украӥна)

ORCID ID: https://orcid.org/0000-0001-7447-4776

\begin{abstract}
Анотація. У статті представлено результати опитування педагогічних працівників щуодо ефективності власної навчальної діяльності. Питання анкети побудовані відповідно до авторської моделі навчальної самоефективності особистості, щуо включає: смисловий, самооціночний, мотиваційно-цілььовий, рефлексивний компоненти. У процесі анкетування виявлено життєві смисли навчання педагогічних працівників серед яких провідними є професійні та прагматичні. Визначена структура самооцінки навчальної успішності педагога. Проаналізовано особливості самооиінки навчального досвіду, навчальних компетентностей, особистісних якостей, щзо сприяють навчальній ефективності.

У статті показана роль рефлексії навчальних результатів (особистісних змін, психологічних новоутворень), компоненту навчальної самоефективності, ї̈ впливу на становлення педагога суб'єктом власного розвитку. Виявлено вміння педагогів орієнтуватися в освітньому просторі, володіти навичками самомотивації та самопідтримки. Визначені психологічні детермінанти, щзо сприяють навчальній ефективності педагогів, а також психологічні бар'єри, щуо утруднюють процес самонавчання.
\end{abstract}

Ключові слова: навчальна самоефективність, педагогічні працівники, життєві смисли навчання, навчальна мотивація, рефлексія.

Актуальність теми дослідження. Педагогічна діяльність пов'язана 3 постійним процесом оновлення знань і професійних компетенцій. Сучасні тенденції, що спостерігаються у суспільстві і освіті, вимагають від педагога уміння швидко та ефективно навчатися, перевчатися, нарощувати та відновлювати знання і компетентності. Серед цих тенденцій виділяють:

а) євроінтеграційні процеси, що привели до реформування освітньої системи і підвищення вимог до рівня освіченості педагога, відповідності його професійної підготовки до європейських стандартів;

б) комп'ютеризація освітнього процесу, що викликає необхідність оволодіння інфор- 
маційною культурою, вміння ефективного використання інформаційно-комунікативних технологій та медіа ресурсів;

в) впровадження інноваційних технологій в освітній процес, що вимагає від учителя психологічної готовності до нововведень в системі освіти, вміння ефективного освоєння освітніх технологій і застосування їх у практичній діяльності.

Сучасний учитель, щоб бути професіоналом, має опанувати новим мисленням, вмінням ефективно оволодівати новою інформацією, досягати поставленої мети, бути впевненим у власних навчальних здібностях, компетентностях, володіти стратегіями самоуправління та бути суб'єктом власного розвитку. Система освіти «все більше перетворюється у простір осмисленого вибору суб'єктом форм і змісту власної освіти, більш того, суб'єкт навчання тільки тоді може ефективно включитися в систему освіти, коли він сам стає активним суб'єктом побудови і розвитку самої системи освіти. Тому змінюється і вся психологопедагогічна проблематика, яка починає концентруватися навколо питань розвитку та саморозвитку особистості», - зауважує Ю. М. Швалб [4, с. 87].

Щоб стати суб'єктом власного розвитку у педагога має бути високий рівень навчальної самоефективності. Навчальну самоефективність ми розглядаємо як конструкт самосвідомості особистості, що характеризує внутрішню готовність індивіда до активних навчальних дій стосовно освоєння нового змісту діяльності або самовдосконалення набутих компетентностей (навчальних, професійних). Навчальна самоефективність є конструктом, у якому проявляється суб'єктна сутність індивіда, його потреба у самоактивності. Завдяки навчальній самоефективності освітня діяльність стає самодетермінованою, самокерованою. Конструкт навчальної самоефективності (Я-ефективне) виявляється у вербалізованій формі як: усвідомлення життєвого смислу навчання - «для чого мені необхідно вчитися», оцінки власних можливостей - «я можу, здатний вчитися», актуалізації власного бажання - «я хочу вчитися», цілеспрямованості - «я прагну и буду вчитися», прогнозуванні власних змін - «завдяки навчанню я стану, зможу». Навчальна самоефективність $є$ предиктором життєвого успіху людини, допомагає управляти власною навчальною діяльністю, сприяє продуктивності, результативності у професійній діяльності.

\section{Аналіз останніх досліджень та публі-} кацій. Питання розвитку самоефективності педагога розглядали численні зарубіжні і вітчизняні дослідники.

Експериментально доведено вплив самоефективності вчителя на вибір методів навчання, емоційне благополуччя учнів, пізнавальну мотивацію, академічну успішність. 3’ясовано кореляційні залежності між рівнем розвитку самоефективності вчителя та його професійною мотивацією [7] 
На думку С. Шаукат і Х. Ікбал, самоефективність педагога має два виміри: перший, пов'язаний з навчанням - це здібність і компетентність заохочувати і стимулювати учнів до навчання шляхом подолання зовнішніх обставин; другий - 3 особистістю педагога - це впевненість у можливості змінювати власну поведінку та викладання так, щоб вплинути на ефективність навчання учнів [8, с. 82].

Дослідники Г. Міллс та Н. Рейсс [6] підкреслюють, що високий рівень самоефективності, наявні ресурси та навички подолання труднощів допомагають педагогам впоратися 3 професійним стресом. Вплив стресу на особистість залежить від його інтенсивності, тривалості, кількості стресових факторів, рівня знань щодо поведінки у стресовій ситуації та навичок подолання стресу. На думку науковців, педагоги 3 добре розвинутими навичками подолання труднощів, як правило, мають більш високе відчуття самоефективності, ніж ті, які не мають навичок виживання і страждають від негативного впливу стресових ситуацій. Чим частіше педагог підпадає під вплив стресових факторів, не маючи необхідних знань і навичок щодо зниження негативного впливу стресу на поведінку та діяльність, тим більше стрес позначається на його емоційному стані, відчутті самоефективності і результатах професійної діяльності.

Педагог обов'язково має бути високоефективним, підкреслює К. Роджерс,. Освіта це не масив фактів, знання яких має бути про- демонстровано, а процес становлення особистості, мета якого - більш багате і осмислене життя. У досягненні цих цілей учитель - не авторитарна фігура, не носій істини і мудрості, що передає їх учням, а людина, що надає свободу учням знайти власну істину і мудрість. Новий досвід починає цінуватися індивідом у залежності від того, чи допомагає він індивіду функціонувати вільно і з максимальною ефективністю. Отже, щоб допомогти учням бути ефективними у своєму житті, вчитель сам має бути самоефективним, підкреслює вчений [3].

Високо самоефективні педагоги ставлять значно вищі навчальні цілі перед своїми учнями та позитивно впливають на їх розвиток, вказує Р. М. Елліндер. Суттєвими характеристиками високо самоефективних учителів у професійній діяльності є відкритість до критичних зауважень, професійна допитливість, дитино-центризм у виборі методів і технологій навчання [5] .

Для педагогів 3 високим рівнем самоефективності, відмічає І. Є. Макаренко, властиві переконання у тому, що не існує ситуацій, які не мають розв'язання; для них характерна достатньо швидка особистісна реабілітація після професійних помилок та невдач. Водночас, учителі 3 низькою самоефективністю уникають складних ситуацій; упевнені у тому, що складні завдання та доручення не для них; зациклюються на помилках і невдачах; швидко втрачають віру та впевненість у власних 
можливостях [1, с. 266].

Відтак, можна зробити висновок, що увага дослідників, в основному, була сконцентрована на професійній самоефективності, а не на навчальній, що обумовило вибір теми нашого дослідження.

Мета статті - висвітлення результатів дослідження уявлень педагогічних працівників щодо ефективності власної навчальної діяльності.

Завдання дослідження. Емпірично дослідити уявлення педагогів щодо власної навчальної успішності, життєвих смислів навчання, наявності потреби у навчанні і саморозвитку.

Вивчити психологічні детермінанти та психолого-педагогічні умови, що впливають дження проводилося серед педагогів області, що проходили навчання у Дніпропетровському інституті післядипломної педагогічної освіти. Вибірка дослідження конструювалася, виходячи $з$ мети та завдань дослідження, відповідно до критеріїв внутрішньої валідності та репрезентативності. В опитувані взяли участь 104 вчителя різних за стажем роботи та педагогічної категорії.

Життєвий смисл - це мета, цінність, ідеал до якого прагне людина, це те, що хвилює людину та спонукає до діяльності. Усвідомлення індивідом життєвого сенсу навчання стає регулятором поведінки. Життєві смисли трансформуються у конкретні навчальні задачі, які необхідно вирішувати суб'єкту навчання.

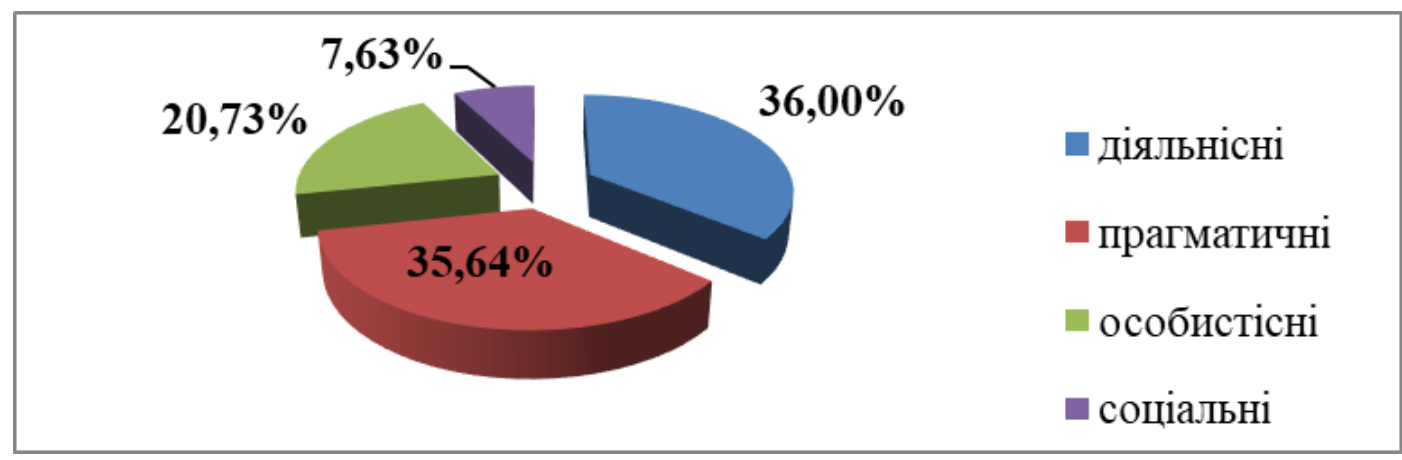

Рисунок 1. Діаграма життсвих смислів навчання (підвищення кваліфікації) педагогічних працівників (\% від загальної кількості смислів)

на ефективність навчальної діяльності педагогів.

3'ясувати психологічні та організаційно-педагогічні бар'єри, що утруднюють функціонування навчальної самоефективності педагогів .

Виклад основного матеріалу. Дослі-
Опитування вчителів області щодо життєвих смислів власного навчання (смисловий компонент навчальної самоефективності) представлено на Рис. 1.

Згідно діаграми найбільше значення для педагогів мають діяльнісні (36,0 \%) і прагматичні $(35,64 \%)$ смисли навчання, меншого 
значення набувають особистісні $(20,73 \%)$ та гів бачать життєвий смисл навчання соціальні (7,63\%) смисли.

Категорії та підкатегорії життєвих сми(підвищення кваліфікації) в оволодінні конкретними методиками, технологіями для успішслів навчання педагогів представлені у Таблиного виконання професійної діяльності. Серед ці 1.

У відповідності до даних таблиці найпрагматичних смислів для опитаних вважливо отримати документ про підвищення кваліфікабільш поширеними є професійні смисли навції для атестації, яка може вплинути на покра-

Таблиия 1.

Уявлення педагогів щодо життсвих смислів власного навчання (підвищення кваліфікації)

\begin{tabular}{|c|c|c|c|}
\hline $\begin{array}{l}\text { Категорії жит- } \\
\text { тсвих смислів } \\
\text { освіти }\end{array}$ & $\begin{array}{c}\text { Підкатегорії жит- } \\
\text { тєвих смислів } \\
\text { освіти }\end{array}$ & $\begin{array}{c}\text { Приклади життєвих смислів отриман- } \\
\text { ня освіти }\end{array}$ & $\begin{array}{c}\text { Кількість } \\
\text { педагогів у } \\
\%\end{array}$ \\
\hline діяльнісні & професійні & $\begin{array}{l}\text { розширити професійні можливості, удо- } \\
\text { сконалити професійні навички, обміня- } \\
\text { тися досвідом, познайомитися з новими } \\
\text { методиками, технологіями навчання }\end{array}$ & 95,19 \\
\hline \multirow[t]{2}{*}{ прагматичні } & $\begin{array}{l}\text { отримання доку- } \\
\text { менту, що підтве- } \\
\text { рджує рівень ква- } \\
\text { ліфікації }\end{array}$ & $\begin{array}{l}\text { отримати посвідчення про підвищення } \\
\text { або підтвердження категорії для атеста- } \\
\text { ції }\end{array}$ & 76,92 \\
\hline & матеріальні & підвищити оплату праці & 17,30 \\
\hline \multirow[t]{4}{*}{ особистісні } & розвивальні & $\begin{array}{l}\text { розвинути творчий потенціал, навички } \\
\text { дослідницької діяльності, інтелектуальні } \\
\text { можливості }\end{array}$ & 16,34 \\
\hline & самореалізації & $\begin{array}{l}\text { розкрити свій потенціал, задовольнити } \\
\text { власні освітні потреби }\end{array}$ & 14,42 \\
\hline & саморегуляції & $\begin{array}{l}\text { розвинути навички самоуправління в } \\
\text { ситуаціях стресу, конфлікту }\end{array}$ & 13,46 \\
\hline & самооціночні & підвищити впевненість у собі & 10,57 \\
\hline \multirow{3}{*}{$\begin{array}{l}\text { соціальні } \\
\text { (соціально- } \\
\text { статусні) }\end{array}$} & $\begin{array}{l}\text { кар'єрні, } \\
\text { статусні }\end{array}$ & зробити кар'єру, стати керівником & 17,30 \\
\hline & комунікативні & покращити навички спілкування & 6,54 \\
\hline & культурні & розвинути педагогічну культуру & 2,88 \\
\hline
\end{tabular}

чання педагогів (розширення професійних можливостей, удосконалення професійних навичок, обмін досвідом, знайомство $з$ новими технологіями навчання). Тобто, більшість педаго- щення фінансового стану педагога. Питання особистісного розвитку, самозмінення, статусні та культурні смисли хвилюють значно меншу кількість педагогів. 
Отже, педагоги, в основному, орієнтовані на «операційну» складову професіоналізму [1]. Вважаємо, що недостатнє розуміння педагогами важливості навчання для розвитку навичок саморегуляції («регуляційна» складова професіоналізму), впевненості у власній майстерності виступає бар'єром у підвищенні навчальної самоефективності та нарощувані професійної майстерності.

У процесі опитування вивчався характер і особливості самооцінки навчальної ефективності педагогів та критеріїв, на які вони орієнтуються. Згідно результатів опитування, усі педагоги впевнені у власних навчальних здібностях та відчувають себе успішними у навчальній діяльності.

Поняття «власна навчальна ефективність» педагоги трактують як професійну самореалізацію $(25,96 \%)$, здатність до самоосвіти $(22,12 \%)$,вміння розкрити свій інтелектуальний потенціал та творчі здібності (20,19\%), професійна компетентність $(14,42 \%)$, здатність до постійного саморозвитку $(8,65 \%)$, уміння швидко та якісно навчатися, самонавчатися (5,76 \%), ефективне використання знань у роботі та повсякденному житті $(2,88 \%)$ тощо.

Отже, до критеріїв навчальної успішності (ефективності) педагоги відносять: 1) професійні якості - здатність до професійної самореалізації, ефективне використання знань у роботі; 2) навчальні компетентності здатність до самоосвіти, уміння розвивати свій інтелектуальний потенціал і творчі здібності, уміння швидко та якісно навчатися, самонавчатися.

Серед особистих якостей, що забезпечують навчальну успішність, педагоги виділяють: відповідальність (24,03 \%), наполегливість $(23,07 \%)$, пізнавальний інтерес $(22,11 \%)$, мотивацію досягнення (19,23\%), прагнення до саморозвитку (9,61%), цілеспрямованість, старанність, терпимість (8,92\%), самоорганізацію (7,69\%), рефлексивність $(5,76 \%)$, любов до роботи $(5,76 \%)$, системне мислення (2,98 \%), адекватне самооцінювання та самокритичність $(2,97 \%)$.

Відтак, 63,71 \% педагогів вважають, що навчальна успішність обумовлена наявністю вольових якостей (відповідальністю, наполегливістю, цілеспрямованістю, самоорганізованістю, терпимістю), 50,95\% опитаних надають перевагу мотиваційним якостям (пізнавальному інтересу, мотивації досягнення, прагненню до саморозвитку), 11,71\% - інтелектуальним якостям (рефлективності, системному мисленню, самокритичності). Слід зазначити, що вольові якості важливі для навчальної самоефективності, однак, такі якості як потреба у саморозвитку $(9,61 \%)$, пізнавальний інтерес $(22,11 \%)$ та рефлексивність $(5,76 \%)$ спонукають особистість до навчання впродовж життя, на них педагоги звертають значно менше уваги.

Згідно відповідей респондентів другим критерієм навчальної успішності $€$ розвиток 
навчальних компетентностей. Самооцінка педагогами навчальних компетентностей за п’я- яльністю $(4,94)$, в умінні працювати з різними інформаційними джерелами $(4,76)$, системати-

\section{Самооцінка педагогами навчальних компетентностей}

\begin{tabular}{|l|l|c|}
\hline $\begin{array}{l}\text { Назва навчальних компе- } \\
\text { тентностей }\end{array}$ & \multicolumn{1}{|c|}{ Зміст навчальних компетентностей } & $\begin{array}{c}\text { Середній } \\
\text { бал }\end{array}$ \\
\hline $\begin{array}{l}\text { Компетентності, що відно- } \\
\text { сяться до самоуправління } \\
\text { навчальною діяльністю }\end{array}$ & $\begin{array}{l}\text { Ефективне управління власною навчальною дія- } \\
\text { льністю }\end{array}$ & 4,94 \\
\hline $\begin{array}{l}\text { Компетентності, що відно- } \\
\text { сяться до управління інфор- } \\
\text { мацісю }\end{array}$ & $\begin{array}{l}\text { Вміння працювати 3 різними інформаційними } \\
\text { джерелами }\end{array}$ & 4,76 \\
\cline { 2 - 3 } & $\begin{array}{l}\text { Вміння систематизувати і узагальнювати навчаль- } \\
\text { ний матеріал }\end{array}$ & 4,76 \\
\cline { 2 - 4 } & $\begin{array}{l}\text { Комп’ютерна грамотність, володіння сучасними } \\
\text { навчальними комп'ютерними програмами }\end{array}$ & 3,87 \\
\hline $\begin{array}{l}\text { Компетентності, що відно- } \\
\text { сяться до управління навча- } \\
\text { льною діяльністю }\end{array}$ & $\begin{array}{l}\text { Вміння здійснювати дослідницьку діяльність } \\
\text { постановка дослідницьких задач, побудова екс- } \\
\text { перименту) }\end{array}$ & 2,63 \\
\hline $\begin{array}{l}\text { Компетентності, що відно- } \\
\text { сяться до управління інфор- } \\
\text { мацією }\end{array}$ & $\begin{array}{l}\text { Володіння іноземними мовами, вміння працювати } \\
\text { з іноземними матеріалами }\end{array}$ & 2,35 \\
\hline
\end{tabular}

тибальною шкалою представлена у Таблиці

2.

За результатами опитування можна стверджувати, що вчителі вважають себе компетентними у самоуправлінні навчальною ді- зувати матеріал $(4,76)$ і менше впевненні у володінні сучасними навчальними комп'ютерними програмами $(3,87)$, в умінні проводити дослідницьку діяльність $(2,63)$, володінні іноземними мовами, що дають можливість праТаблиия 3.

\section{Самооцінка педагогами вміння оріснтуватися в освітньому просторі}

\begin{tabular}{|l|l|c|}
\hline $\begin{array}{l}\text { № } \\
\text { 3/п }\end{array}$ & \multicolumn{1}{|c|}{ Показники освітнього простору } & \multicolumn{1}{|c|}{$\begin{array}{c}\text { Середня } \\
\text { оцінка }\end{array}$} \\
\hline 1. & $\begin{array}{l}\text { Володіє інформацією та можете здійснювати вибір навчальних програм: } \\
\text { - в інституті післядипломної освіти, } \\
\text { - у закладах неформальної освіти (тренінгових центрах, } \\
\text { тощо) }\end{array}$ & 4,52 \\
\hline 2. & $\begin{array}{l}\text { Вміє знаходити консультантів, експертів для рішення задач власного розвит- } \\
\text { ку (освіти) }\end{array}$ & 4,34 \\
\hline 3. & Володіє Інтернет - простором для задоволення власних освітніх потреб & 4,28 \\
\hline 4. & володіє інформацією, щодо задоволення власних освітніх потреб в Україні & 3,15 \\
\hline 5. & $\begin{array}{l}\text { володіє інформацією, щодо задоволення власних освітніх потреб в країнах } \\
\text { СС (світу) }\end{array}$ & - \\
\hline
\end{tabular}


цювати з іноземними джерелами $(2,35)$.

Самооцінка педагогами вміння орієнтуватися в освітньому просторі (компетентність особистісного самовдосконалення) - за п'ятибальною шкалою представлена у таблиці 3.

Педагоги добре орієнтуються у навчальному просторі інституту післядипломної освіти, вміють знаходити консультантів, експертів для рішення задач власного розвитку, використовують Інтернет-простір. У той же час, майже не володіють інформацією щодо задоволення власних освітніх потреб у закладах неформальної освіти та в навчальних закладах інших країнах ЄС (світу). Тобто, вчителі орієнтуються лише у просторі вітчизняної формальної освіти, що є недостатнім у сучасному глобалізованому світі.

Отже, згідно отриманих результатів, дальності, наполегливості), відчувають себе компетентними у самоуправлінні навчальною діяльністю, в умінні працювати з різними інформаційними джерелами та систематизувати інформацію.

Джерелом навчальної самоефективності є навчальний досвід. Пережитий успіх у досягненні навчальних результатів допомагає педагогу в емоційній саморегуляції, особливо в ситуаціях стресу (атестація тощо). Найбільш важливим для навчальної самоефективності $€$ успішний досвід у самонавчанні. Чим успішнішим $є$ навчальний досвід індивіда у самонавчанні, тим краще він володіє стратегіями власного розвитку, має психологічну готовність до самоосвіти впродовж життя.

Вивчення наявності успішного навчального досвіду у досліджуваних показало, що

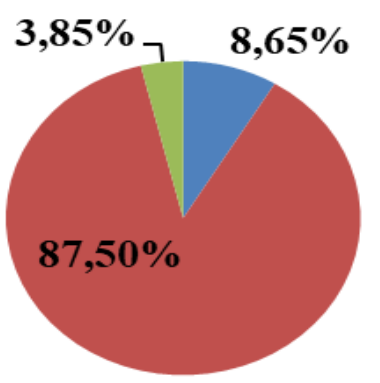

- успішний навчальний досвід тільки у ВНЗ

в успішний навчальний досвід у різних навчальних закладах

відсутність успішного навчального досвіду

\section{Рисунок 2. Діаграма навчального досвіду педагогів}

особливістю самооцінки навчальної ефективності педагогів $\epsilon$ те, що іï структура складається 3 внутрішніх показників: особистісних якостей та навчальних компетентностей. Серед особистісних якостей опитані перевагу надають вольовим якостям (особливо відпові-
96,15 \% педагогів вказують на успішний навчальний досвід у виші, 3 них 87,50 \% також його мали у школі та інших навчальних закладах, 3,85\% опитаних не змогли визначитися 3 відповіддю (Рис. 2.).

Таким чином, більшість педагогів кон- 
статують успішний навчальний досвід не тільки у виші, а й інших навчальних закладах. Проте, у 3,85 \% відсутній позитивний навчальний досвід, що може негативно позначитися на умінні протистояти труднощам у самонавчанні і саморозвитку та на готовності вчитися впродовж життя.

Психологічний бар'єр у навчанні є внутрішньою перешкодою, що заважає педагогу успішно здійснювати самоосвіту та саморозвиток. Бар'єри супроводжуються виникненням напруженого психічного стану, неадекватною пасивністю суб'єкта, гальмуванням активності, низької самооцінкою. Аналіз бар'єрів, що впливають на навчальну ефективність педагогів показав, що їх можливо поділити на дві групи - внутрішні і зовнішні. До внутрішніх психологічних бар'єрів педагоги відносять: низьку навчальну мотивацію - 48,4 \%, упередженні думки, страхи та негативні стереотипи,(наприклад: «тільки через професійний досвід педагог набуває майстерності», «все нове (інновації) - це добре забуте старе», «мені вже пізно перевчатися», «професійний вчитель, чи ні, оплата праці однаково низька») - 16,11\%, не впевненість у собі $14,88 \%$, недостатню самоорганізацію $6,87 \%$, лінощі - 6,87 \% тощо. Наявність низької навчальної мотивації, на наш погляд, обумовлена організаційними та соціальними аспектами діяльності педагога (перенавантаженням, низькою оплатою праці, низьким соціальним статусом тощо), що призводить до професійного вигорання, розчарування у професії, депресивним настроям.

Серед зовнішніх бар'єрів, що перешкоджають навчальній ефективності, педагоги виділили: нестачу часу (92,2 \%), надмірне навантаження $(30,9 \%)$, зайву роботу $(14,88 \%)$, нестачу коштів на придбання необхідної літератури, комп'ютерних навчальних програм (14,88\%) тощо. Переважання бар'єрів «нестача часу» та «надмірне навантаження», на наш погляд, може вказувати, для молодих вчителів на проблеми адаптації до професії, а для вчителів, що мають значний стаж роботи, на ознаки професійного вигорання. Вважаємо, що це є найпоширенішими бар'єрами, і саме

\section{Таблиия 4.}

Психологічні інструменти самомотивації, самопідтримки, які застосовують педагоги

\begin{tabular}{|c|l|c|}
\hline $\begin{array}{c}\text { № } \\
\text { 3】п }\end{array}$ & $\begin{array}{c}\text { Психологічні інструменти емоційної саморегуляції, само- } \\
\text { мотивації }\end{array}$ & $\begin{array}{c}\text { Кількість педагогів } \\
\mathbf{y} \%\end{array}$ \\
\hline 1. & Самопереконання, самопідбадьорення & 62,31 \\
\hline 2. & Заняття творчістю & 30,9 \\
\hline 3. & Приклади з соціального оточення & 23,8 \\
\hline 4. & Візуалізації ( «Я успішна людина») & 6,87 \\
\hline 5. & Інші & 16,81 \\
\hline
\end{tabular}


вони виступають у якості психологічних захистів, за якими особистість приховує своє небажання нарощувати професійну майстерність.

Для подолання психологічних бар'єрів, які заважають навчальній ефективності, опитані застосовують психологічні прийоми емоційної саморегуляції та самомотивації. Аналіз психологічних інструментів самопідтримки, що застосовують педагоги представлено у Таблиці 4.

Значна кількість педагогів у ситуації невпевненості використовують прийоми самопереконання, самопідбадьорення, менше орієнтуються на творчість, приклади соціального оточення та візуалізацію. Серед інших прийомів самомотивації були названі самонаказ, вміння відмічати навіть незначний успіх при освоєнні нового навчального матеріалу. Згідно результатів опитування, можна констатувати, що більшість педагогів мають вузький спектр психологічних інструментів самомотивації та емоційної саморегуляції, який потребує розширення.

Здатність до самостійної постановки цілей саморозвитку, характеризує не суб'єкт навчання, а більш високий рівень зрілості особистості - суб'єкта власного розвитку. Те, які цілі визначає для себе індивід, вказує на рівень розвиненості його навчальної самоефективності і його психологічну зрілість.

За опитуванням $76,92 \%$ респондентів визначають цілі власного розвитку, самовдос- коналення які, в основному, стосуються професійної сфери. Майже чверть педагогів $(23,08 \%)$ не змогли визначитися з відповіддю, що вказує на те, що педагоги не замислюються над цілями власного розвитку, їх хвилює розвиток учнів. Нездатність конкретизувати цілі власного розвитку вказує на неготовність частини педагогів до саморозвитку через освіту (самоосвіту) та навчання впродовж життя.

Вивчення зовнішніх соціальнопсихологічних чинників та умов, що детермінують навчальну ефективність педагогів виявило, що для опитуваних важливі: інноваційно-творча атмосфера педагогічних колективів (30,09\%), підтримка колег i адміністрації $(23,63 \%)$, фінансові можливості $(19,04 \%)$, задоволеність умовами праці $(13,76 \%)$, вільний вибір форм і закладів підвищення кваліфікації (7,69 \%), участь у конкурсах, нагороди, що підвищують соціальний статус педагога $(5,76 \%)$.

Відтак, за допомогою анкетування були виявлені особливості самооціночного, смислового, цільового аспектів навчальної самоефективності педагогів. Здатність до навчальної рефлексії вивчалася за допомогою контентаналізу. Респондентам було запропоновано написання есе «Вплив навчання на курсах підвищення кваліфікації на розвиток особистості педагога». Результати контент-аналізу есе представлено у Таблиці 5.

Дані таблиці засвідчують, що більшість респондентів у процесі навчання відзначають 
Результати контент-аналізу есе педагогів

\begin{tabular}{|c|c|c|c|}
\hline $\begin{array}{l}\text { № } \\
\text { 3/II }\end{array}$ & $\begin{array}{l}\text { Категорії кон- } \\
\text { тент-аналізу }\end{array}$ & $\begin{array}{l}\text { Підкатегорії } \\
\text { контент- } \\
\text { аналізу }\end{array}$ & $\begin{array}{c}\text { Одиниці аналізу (слово, словосполучення) та } \\
\text { частота згадувань у \% }\end{array}$ \\
\hline \multirow[t]{3}{*}{1.} & \multirow[t]{3}{*}{$\begin{array}{l}\text { Компоненти } \\
\text { педагогічної } \\
\text { майстерності }\end{array}$} & $\begin{array}{l}\text { професійні } \\
\text { знання }\end{array}$ & $\begin{array}{l}\text { розширення: знань з предмету, що викладається } \\
(55,35 \text { \%), знань з гуманітарних дисциплін } \\
(8,92 \%)\end{array}$ \\
\hline & & $\begin{array}{l}\text { професійні ком- } \\
\text { петентності }\end{array}$ & $\begin{array}{l}\text { оволодіння новими методиками навчання } \\
(67,85 \%) \text {; удосконалення професійних компетен- } \\
\text { тностей }(63,09 \%) \text {; освоєння нових комп’ютер- } \\
\text { них програм }(35,11 \%) \text {; вміння проводити дослід- } \\
\text { ницьку роботу }(26,78 \%) \text {, вміння застосовувати } \\
\text { інтерактивні методи навчання }(14,88 \%)\end{array}$ \\
\hline & & $\begin{array}{l}\text { відношення до } \\
\text { праці }\end{array}$ & підвищення інтересу до професії $(22,61$ \%) \\
\hline \multirow[t]{2}{*}{2.} & \multirow[t]{2}{*}{$\begin{array}{l}\text { Особистість } \\
\text { педагога }\end{array}$} & якості & $\begin{array}{l}\text { вміння протидіяти стресу }(14,88 \%) \text {, вміння } \\
\text { управляти конфліктом }(11,30 \%)\end{array}$ \\
\hline & & самооцінка & більше впевненості у собі $(11,30$ \%) \\
\hline 3. & $\begin{array}{l}\text { Взаємодія з ін- } \\
\text { шими учасни- } \\
\text { ками навчаль- } \\
\text { ного процесу }\end{array}$ & & $\begin{array}{l}\text { розширення професійного кола спілкування } \\
(65,47 \%) ; \text { обмін професійним досвідом } \\
(35,11 \%) ; \text { вміння працювати у групах, командах } \\
(5,35 \%)\end{array}$ \\
\hline
\end{tabular}

зміни у професійних знаннях та компетентностях, у розширенні професійного кола спілкування. Значно менша частина опитаних вказують на зміни в особистісній та мотиваційних сферах (вмінні протидіяти стресу, вмінні управляти конфліктом, підвищенні інтересу до професіі). Проведений контент-аналіз показав, що педагоги схильні у процесі рефлексії акцентувати увагу на отриманих знаннях та компетентностях. Рефлексію емоційного стану та особистісної сфери здійснює незначна кількість респондентів.

Висновки. Відтак, згідно проведеного дослідження, можна зробити висновки:

- у педагогів переважають професійні та прагматичні смисли навчання;

- життєві смисли навчання орієнтовані на операційну складову професіоналізму (оволодінні конкретними методиками, технологіями для успішного виконання професійної діяльності);

- структура самооцінки навчальної успішності педагогів складається тільки 3 внутрішніх критеріїв: навчальних компетентностей, професійних та особистісних якостей, серед яких найбільше значення мають вольові якостi;

- педагоги вільно орієнтуються у просторі вітчизняної формальної освіти, у той же час, майже не володіють інформацією щодо задо- 
волення власних освітніх потреб у закладах неформальної освіти та в закладах інших країн ЄС (світу);

• найбільш поширеними психологічними бар'єрами, що заважають здійснювати самоосвітню діяльність для педагогів, є нестача часу, низька навчальна мотивація, надмірне навантаження, що вказує на ознаки професійного вигорання, упередженні думки, страхи;

- навчальні цілі більшості педагогів стосуються професійної сфери, майже чверть педагогів не можуть конкретизувати цілі власного розвитку, що вказує на несформованість суб'єктної позиції стосовно самозмінення, самовдосконалення;

- детермінують навчальну ефективність педагогів соціально-психологічні чинники: інноваційно-творча атмосфера педагогічних колективів, фінансові можливості, задоволеність умовами праці, вільний вибір форм i закладів підвищення кваліфікації (формальна, неформальна та інформальна освіта), участь у конкурсах, нагороди, що підвищують соціальний статус педагога.

\section{Перспективу подальших досліджень} ми бачимо у розробці психологічної моделі розвитку навчальної самоефективності педагогічних працівників.

\section{Список використаних джерел:}

1. Макаренко I. С. Роль самоефективності педагога в забезпеченні його високих професійних досягнень / I.Є. Макаренко // Педагогіка формування творчої особис- тості у вищій і загальноосвітній школах :зб. наук. пр. / [редкол.: Т. І. Сущенко (голов. ред.) та ін.]. - Запоріжжя : КПУ, 2014. - Вип. 37 (90). - С. 263-270.

2. Маркова А. К. Психология профессионализма / А. К Маркова. - М.: Международный гуманитарный фонд Знание, 1996. - 312 c.

3. Роджерс К. Личностно-центрированная терапия / К. Роджерс, Б.Мидор // Журнал практической психологии и психоанализа. [Электронный ресурс]. - 2002. № 4.

(5) - Режим доступа - http://www.psyjournal.ru

4. Швалб Ю. М. Методология и теория экспертной деятельности: психологические аспекты: монография / Юрий Михайлович Швалб. - К.: «Основа», 2013. - 240 c.

5. Allinder R. M. The relationship between efficacy and the instructional practices of special education teachers and consultants / R. M. Allinder // Teacher Education and Special Education.- 1994.- Vol.17. - P. 86-95.

6. Mills $H$. Self-Efficacy and the Perception of Control in Stress Reduction. Mental Help. / H.Mills, N.Reiss, M.Dombeck [Електронний pecypc]. - 2008 - Режим доступа: https://www.mentalhelp.net/articles

7. Pajares $F$. Gender and perceived self-efficacy in selfregulated learning / F.Pajares //Theory into Practice, 2002 - Vol. 41 . - P.116-125

8. Shaukat $S$. Teacher self-efficacy as a function of student engagement, instructional strategies and classroom management / S.Shaukat, H.M.Iqbal // Pakistan Journal of Social and Clinical Psychology, 2012. - Vol.9. - № 3. - P. 82-85.

\section{References (Transliteration):}

1. Makarenko I. Ie. Rol samoefektyvnosti pedahoha v zabezpechenni yoho vysokykh profesiinykh dosiahnen / I.Ie. Makarenko // Pedahohika formuvannia tvorchoi osobystosti u vyshchii i zahalnoosvitnii shkolakh :zb. nauk. pr. / [redkol.: T. I. Sushchenko (holov. red.) ta in.]. Zaporizhzhia : KPU, 2014. - Vyp. 37 (90). - S. 263-270.

2. Markova A. K. Psihologiya professionalizma / A. K Markova. - M.: Mezhdunarodnyiy gumanitarnyiy fond 
Znanie, 1996. - $312 \mathrm{~s}$.

3. Rodzhers K. Lichnostno-centrirovannaya terapiya / K. Rodzhers, B.Midor // Zhurnal prakticheskoj psihologii i psihoanaliza. [Elektronnyj resurs]. - 2002. № 4. (5) Rezhim dostupa - http://www.psyjournal.ru

4. Shvalb Yu. M. Metodologiya i teoriya ekspertnoy deyatelnosti: psihologicheskie aspektyi: monografiya / Yuriy Mihaylovich Shvalb. - K.: «Osnova», 2013. - 240 s.

5. Allinder $R$. M. The relationship between efficacy and the instructional practices of special education teachers and consultants / R. M. Allinder // Teacher Education and Special Education.- 1994.- Vol.17. - P. 86-95.

6. Mills $H$. Self-Efficacy and the Perception of Control in Stress Reduction. Mental Help. / H.Mills, N.Reiss, M.Dombeck [Електронний ресурс]. - 2008 - Режим доступа:https://www.mentalhelp.net/articles

7. Pajares $F$. Gender and perceived self-efficacy in selfregulated learning / F.Pajares //Theory into Practice, 2002 - Vol. 41 . - P.116-125

8. Shaukat $S$. Teacher self-efficacy as a function of student engagement, instructional strategies and classroom management / S.Shaukat, H.M.Iqbal // Pakistan Journal of Social and Clinical Psychology, 2012. - Vol.9. - № 3. - P.8285.

\section{Galtseva Tatiana}

PhD (psychological sciences), associate professor, associate professor of the department of social and humanitarian disciplines in Dnipropetrovsk State University of Internal Affairs, Dnipro (Ukraine)

\section{DIAGNOSTIC OF PEDAGOGICAL WORKERS OPINION ABOUT EFFICIENCY OF THEIR OWN EDUCATIONAL ACTIVITY}

\begin{abstract}
The article shows trends in education that require teachers to quickly, effectively learn, retrain, build up their knowledge and competence.
\end{abstract}

Defined the concept of academic self-efficacy as a phenomenon of individual consciousness that characterizes person's confidence in their own abilities and opportunities to actively and productively implement educational and cognitive activity, to achieve personal and meaningful learning outcomes that will contribute to self-motion, selfdevelopment, self-improvement of personality. Besides that, defined was the characteristic that also finds personal qualitative changes in the process of transformation of the subject of educational activity in subject's own development.

An analysis of recent studies and publications concerning the impact of self-efficacy on the results of professional activity of teachers was carried out. The results of the survey of teachers about the efficiency of their own educational activities are presented. The questionnaire was created in accordance with author's model of selfefficacy of the individual, which includes: semantic, self-assessing, motivational-target and reflexive components.

In the process of questioning, life skills were identified as the teaching of pedagogical workers, among which the leading ones are professional and pragmatic. The structure of selfassessment of teacher's educational success was determined. The article analyzes the peculiarities of self-assessment of educational experience, educational competences, personal qualities contributing to educational effectiveness. The article shows the role of reflection on educational results (personal changes, psychological neoplasms), the 
component of educational self-efficacy, its influence on the formation of a teacher as a subject of own development. The teacher's ability to orient themselves in the educational space, to master the skills of self-motivation and self-support is revealed. The psychological determinants contributing to the educational effectiveness of teachers, as well as psychological barriers hindering the process of self-education are determined.

Key words: educational self-efficacy, pedagogical workers, vital sense of learning, educational motivation, reflection.

\section{Гальцева Татьяна Алексеевна}

Кандидат психологических наук, дочент, доцент кафедры сочиально-гуманитарных дисциплин Днепропетровского государственного университета внутренних дел, г. Днепр (Украина)

\section{ДИАГНОСТИКА ПРЕДСТАВЛЕНИЙ ПЕДАГОГИЧЕСКИХ РАБОТНИКОВ ОБ ЭФФЕКТИВНОСТИ СОБСТВЕННОЙ УЧЕБНОЙ ДЕЯТЕЛЬНОСТИ}

Аннотация. В статье показано тенденции, происходящие в образовании, требующие от педагогов умение быстро, эффективно учиться, переучиваться, наращивать знания и компетентности. Осуществлен анализ последних исследований и публикаций по вопросам влияния самоэффективности на результаты профессиональной деятельности педагогов. Представлены результаты опроса педагогов об эффективности собственной учебной деятельности.

Вопросы анкеты были построены в со- ответствии с авторской модели учебной самоэффективности личности, которая включает: смысловой, самооценочный, мотивационно-целевой, рефлексивный компоненты. В процессе анкетирования выявлены жизненные смыслы обучение педагогических работников, среди которых ведущими являются профессиональные и прагматичны. Определена структура самооценки учебной успешности педагога. Проанализированы особенности самооценки учебного опыта, учебных компетентностей, личностных качеств, способствующих учебной эффективности.

В статье показана роль рефлексии учебных результатов (личностных изменений, психологических новообразований), компонента учебной самоэффективности, ее влияния на становление педагога субъектом собственного развития. Выявлено умение педагогов ориентироваться в образовательном пространстве, владеть навыками самомотивации и самоподдержки.

Определены психологические детерминанты, способствующие учебной эффективности педагогов, а также психологические барьеры, затрудняющие процесс самообучения.

Ключевые слова: учебная самоэффективность, педагогические работники, жизненные смыслы обучения, учебная мотивация, рефлексия.

Дата отримання статті: 17.05.2018 Дата рекомендації до друку: 15.06.2018 Дата оприлюднення: 02.07.2018 